\title{
Cutaneous manifestations in senile skin in coastal Goa
}

Pavithra $\mathrm{S}^{1}$, Shukla $\mathrm{P}^{2}$, Pai GS ${ }^{3}$

${ }^{1}$ Assistant professor, Yenepoya Medical College, Managalore ,Karnataka, India

${ }^{2}$ Professor \& HOD Dept of Dermatology,Goa Medical College

${ }^{3}$ Medical Director, Derma-care, Ex Professor and HOD of KMC Mangalore

\section{Correspondence}

Dr. S. Pavithra

126 A , Syndicate bank quarters

Manipal, Karnataka- 576104

docpavithra@gmail.com

Source(s) of support, conflicts of interests, prior presentation: Nil

\begin{abstract}
Background

Discoveries in medical sciences and improved social conditions during the past few decades have increased human life span thereby leading to an increasing segment of geriatric population. ${ }^{1}$ Senescence in the skin is a gradual process that ultimately results in the appearance and functional differences that we associate with age. ${ }^{2}$ The increasing segment of geriatric population are noted to have characteristic group of dermatoses which can be called as geriatric dermatoses. Such dermatoses may be expressed as cutaneous changes intrinsic to chronological ageing. Alternatively there may be other unrelated dermatoses having an altered expression on the geriatric skin.
\end{abstract}

\section{Aims}

This study aims to delineate the spectrum of various geriatric dermatoses among the hospital population at Goa Medical College (GMC).

\section{Methods}

This was a prospective study done over a period of one year in the department of dermatology, Goa Medical College. Patients above the age of 60 years presenting to the dermatological outpatient in GMC, patients referred from other wards were included in the study. A detail history and thorough clinical examination was done of every patient above 60 years who presented with skin complaints. A clinical photograph was taken of the relevant skin changes. Relevant investigations pertaining to the study were carried out to support the clinical findings.

\section{Results}

Of the 411 geriatric patients above 60 years, males (64.7\%) outnumbered females (35.3\%). Age group of 65-69 years constituted a maximum $(57.9 \%)$ number of geriatric patients. Amongst the geriatric dermatoses, wrinkling of skin $(99.3 \%)$ and graying of hair $(96.8 \%)$ outnumbered all other findings. This was followed by benign neoplasias (80.5\%). Fungal infections $(20.7 \%)$, eczemas $(19.2 \%)$, papulosquamous disorders $(12.3 \%)$, senile pruritus $(9.2 \%)$, senile comedones $(8.5 \%)$, fissured soles $(6.8 \%)$, xerosis and leg ulcers $(6.6 \%)$ each, pigmentory disorders (5.8\%), infestation (4.9\%), vesiculobullous disorders $(4.4 \%)$, senile purpura and immune, rheumatic disorders (4.1\%) each. $3(0.7 \%)$ malignant cases were reported. Graying of hair $(96.8 \%)$ and alopecia $(32.55 \%)$ were the ageing related hair changes seen. Among the nail disorders, longitudinal ridges (12.6\%) was the commonest followed by nail discoloration (10.2\%), subungual hyperkeratosis (7.3\%), onycholysis $(7.5 \%)$, onychomycosis and nail distortion (5.8\%) each, pitting of nails (5.0\%).

\section{Conclusion}

The skin is marker of systemic disease. With variation of geographical distribution in Goa, most common cutaneous findings are physiological aging signs, benign legions and very rarely malignant cutaneous changes have been seen.

\section{Keywords}

Ageing, geriatric, dermatoses, intrinsic, chronological, biopsies. 


\section{Introduction}

In both developed and developing nations, the number and proportion of older people are increasing. Government and institutions arbitrarily defines geriatric populations as those persons over 65 years of age. ${ }^{3}$ Senescence in the skin is a gradual process that ultimately results in the appearance and functional differences that we associate with old age. ${ }^{2}$ Age of a person has a definitive impact on the type of dermatoses seen in clinical practice. Hence different age groups like infancy, childhood, adulthood have their own distinctive dermatoses which are a hallmark or are more prevalent in that age group. Similarly the increasing segment of geriatric population is noted to have characteristic group of dermatoses which can be called as geriatric dermatoses. These dermatoses may be expressed as cutaneous changes intrinsic to chronological ageing. Alternatively there may be other unrelated dermatoses having an altered expression on the geriatric skin.

Cutaneous ageing including 2 distinct phenomena- True ageing also termed as the intrinsic ageing is a universal, presumably inevitable change attributable to the passage of time alone. Photoaging is the superposition on intrinsic ageing of changes attributable to chronic sun exposure which are neither universal nor inevitable. The former is manifested primarily by physiologic alteration with subtle but undoubtedly important consequences for both healthy and diseased skin, the latter has major morphologic as well as physiologic manifestations and corresponds more closely to the popular notion of 'old skin.' Intrinsic changes of ageing fall into 2 categories: Those that appear to be engendered within the tissues themselves, and those that are the result of alterations, including hormonal cost by senile changes in other organs. ${ }^{2}$ The swelling groups of geriatric population with their chronic manifestation is forming a significant proportion of patient. Hence the present study was undertaken to delineate the feature of geriatric dermatoses in our part of the country.

\section{Methods}

This was a prospective study done over a period of one year in the department of dermatology, Goa Medical College. During this period (from Feb 2006-2007), 411 geriatric patients who were 60 years and above in age were seen. Apart from outpatients and inpatients of dermatology department, patients referred or transferred from other wards with skin complaints were also included in the study. The findings were then noted in a specially prepared proforma which included the patients' history, examination and investigations findings. A clinical photograph was taken of the relevant skin changes. Relevant investigations pertaining to the study were carried out which included the following: skin biopsy, Tzanck smear, $\mathrm{KOH}$, blood counts, liver function test, renal function test, fasting and post prandial blood sugar levels etc. Out of the 411 patients, 266 patients were biopsied. The remaining 145 patients came under the exclusion criteria for biopsy which included the following - senile pruritus, xerosis, infections, infestations, fissured soles, leg ulcers, alopecias. Most of the biopsies were conducted from clinically identifiable lesion. The histopathological slides prepared thereafter were evaluated visually and photomicrographs were recorded. Most of the histopathological features observed in our study correlated with the clinical findings. The data and observations was then compiled, tabulated and statistically summarized. Finally a master chart was prepared showing all the patient details enrolled in the study with their history, examination findings, investigations and diagnosis.

\section{Results}

Of the 411 patients enrolled in the study, males (64.7\%) outnumbered females (35.3\%) with 2:1 male to female ratio. Age group of 65-69 years constituted a maximum (57.9\%) number of geriatric patients. This was followed by age groups $60-64$ years (18.7\%) and $70-74$ years (17.5\%). A relatively lesser incidence $(4.6 \%)$ of patients formed the 75-79 years age group. Small proportions $(1.2 \%)$ of patients were above 80 years of age. Majority of our patients (70.1\%) had the dermatoses for more than 4 weeks period before presenting to us. In our study amongst the geriatric dermatoses a high percentage of patients had wrinkling of skin (99.3\%) and graying of hair (96.8\%) which outnumbered all other findings. This was followed by benign neoplasias (80.5\%). Fungal infections (20.7\%), eczemas (19.2\%) papulosquamous disorders (12.3\%), senile pruritus (9.2\%), senile comedones $(8.5 \%)$, fissured soles $(6.8 \%)$, xerosis and leg ulcers $(6.6 \%)$ each, pigmentary disorders $(5.8 \%)$, infestation (4.9\%), vesiculobullous disorders (4.4\%), senile purpura and immune, rheumatic disorders (4.1\%) each were the other recorded conditions. A relatively low incidence of patients had bacterial infections (3.9\%), viral infections (3.4\%), oral cavity disorders $(3.2 \%)$, pressure sores (2.9\%), disorders of sun exposure (2.4\%), xanthelasma (1.4\%), drug rash (1.2\%), malignancies, Hansen's and erythema multiforme (0.7\%) each. We found a single $(0.2 \%)$ case each of tuberculosis verrucosa cutis, Darier's disease and lichen sclerosis et atrophicus of vulva. Among the hair disorders graying of hair 
(96.8\%), was present in majority of patients followed by alopecia (non-cicatricial) (32.55\%). Among the nail disorders, longitudinal ridges (12.6\%) were the commonest. Others were nail discoloration (10.2\%), subungual hyperkeratosis (7.3\%) onycholysis (7.5\%), onychomycosis and nail distortion (5.8\%) each, pitting of nails (5.0\%), beau's lines and lusterless nails (1.9\%) each, onychogryphosis $(1.0 \%)$, onychauxis and onychoszhia $(0.7 \%)$ each, edema of nail folds and triangular nicking of nails in $(0.2 \%)$ each.

\section{Discussion}

During the study period of one year 411 geriatric patients were seen. We considered a lower age limit of 60 years as the inclusion criteria for our patients which is similar to the studies done by Verbov $\mathrm{J}^{5}$, Chopra $\mathrm{A}^{6}$ and Lane and Rockwood ${ }^{7}$. Of the 411 patients, Males (64.7\%) outnumbered females (35.3\%) with 2:1 male to female ratio. This is similar to the findings of Patange V. $S$ et $\mathrm{al}^{8}$. However Lane and Rockwood ${ }^{7}$ observed more number of females than males in their study. In our series, age group of 65-69 years constituted a maximum (57.9\%) number of geriatric patients. Age groups 6064 years $(18.7 \%)$ and $70-74$ years $(17.5 \%)$ were next in frequency. A relatively lesser incidents (4.6\%) of patients formed the 75-79 years age group. These findings of ours could not be strictly compared with studies done before as they have had different latitudes for age groups and age limit. Some studies ${ }^{8}$ had age group 55-64 years (66.6\%) as the commonest and relatively few (25.5\%) formed 65-75 year age group. However some ${ }^{9}$ found a high proportion of patients in the age group 80-91 and 70-79 years respectively and a relatively low number of patients formed the 60-69 and 50-59 age groups as compared to our series. Majority of our patients (70.1\%) had the disease for more than four weeks period before presenting to us. An almost equal proportion of patients (14.3\%) and (13.1\%) had the dermatoses for less than two weeks and for a two to four week period respectively before seeking medical attention. A high proportion of patients with duration of disease more than 4 weeks could be due to the fact that most dermatoses in geriatric age group do not contribute to morbidity and mortality, hence are neglected for variable period of time before presenting for medical attention. Moreover it is also possible that elderly patients are often debilitated and dependent on others to avail medical services while others are neglected and hence the delay. In our studies amongst the geriatric dermatoses a high percentage of patients had wrinkling of skin (99.3\%) and graying of hair $(96.8 \%)$ which outnumbered all other findings. These were specifically looked for in our patients as they are considered to be as specific science of ageing as mentioned by standard text books. 4 However other workers $5,7,9,10$ have not included these changes except by Chopra $\mathrm{A}^{6}$ probably as they do not form a part of presenting complaints and are considered to be invariably associated with ageing. Senile pruritus accounted for $(9.2 \%)$ of patients in our series. Yalcin et $\mathrm{al}^{12}$ noted a slightly higher number (11.55\%) while other studies ${ }^{6}$, $7,8,10$ showed a lower incidence. Xerosis constituted (6.6\%) of patients similar to that done by Patange V. S et $\mathrm{a}^{8}$ However other studies ${ }^{9}$ reported a significantly higher incidence (85.1\%). Goa being a humid costal area explains for the lower incidence of patients with xerosis.

Seborrhoeic keratosis and cherry angiomas accounted for $27.5 \%$ and $20.9 \%$ of patients respectively. Our results are thus different to some studies, ${ }^{8,9}$ which showed a higher incidences while others $5,6,7$ which showed a lower incidence are compared to ours. The reason for a wide variation of this could be partly explained by the fact that seborrhoeic keratosis occur more commonly in fair skinned individuals and the incidence relatively decreases in darker skin types i.e. type IV and type $\mathrm{V}^{8,9}$. We encountered $(24.6 \%)$ of patients with skin tags which was similar to that reported by Patange V.S et $\mathrm{al}^{8}$. However Verbov $\mathrm{J}^{5}$ reported a comparatively lower number of patients having these dermatoses. The incidence of dermatoses papulosa niagra (DPN) (5.3\%) and colloid milia $(2.2 \%)$ were relatively lower as compared to the other benign neoplasias. A higher incidence (58.8\%) of patients with DPN was reported by Beauregard S. et $\mathrm{al}^{9}$

The incidence of senile comedones was found to be $(8.5 \%)$ in our patients which is little lower than that reported by other studies ${ }^{8}$. Senile purpura was seen in $(4.1 \%)$ of patients in our series. Other workers, ${ }^{8,9}$ represented a higher incidence as compared to ours. Eczemas accounted for (19.2\%) of our patients consistent with the findings of the other studies ${ }^{8,12}$. some workers $^{6,7}$ showed a lower incidence of eczemas in their papers as compared to ours. Among the eczemas the incidence of asteatotic eczemas was the highest (5.6\%). This was closely followed by stasis eczema (4.1\%), Lichen simplex chronicus (3.9\%), contact dermatitis (2.4\%), nummular eczemas $(2.2 \%)$, prurigo nodularis $(0.7 \%)$. Asteatotic eczema accounted for a lower incidence of (2.3\%) patients in $\mathrm{Mc}$ Fadden $\mathrm{N}$ et $\mathrm{a}^{10}$ study. However it was one of the commonest eczema reported by Weismann $\mathrm{K}$. et $\mathrm{al}^{11}$ with a high incidence of $(28.9 \%)$ which they attributed to be because of excessive use of soaps and shampoos and lower humidity in their institutions. Goa being a humid coastal area explains for the low incidence of this eczema. Stasis eczema also showed a slightly high incidence $(6.9 \%)$ in their group as compared to ours. Both 
asteatotic eczema and stasis eczema was less commonly encountered in Patange V S et al8 study. The incidence of contact dermatitis in groups ${ }^{8,9}$ were $(7.5 \%)$ and $(11.8 \%)$ respectively which is much higher as compared to our study however some groups ${ }^{10,11}$ reported an incidence of $(3.8 \%)$ and (3.5\%) closer to ours. Blistering disorders were noted in $(4.4 \%)$ of the patients in our series close to $(3.6 \%)$ as reported by verbov J et $\mathrm{al}^{5}$. However Yalcin et $\mathrm{al}^{12}$ and Chopra $\mathrm{A}^{6}$ reported a lower incidence of $1.5 \%$ and $2.9 \%$ respectively in their groups. The incidence of fungal infections was (20.7\%) in our patients as against (18.5\%) and (15.8\%) reported by following studies ${ }^{8,12}$ respectively. Some workers ${ }^{5,7}$ reported a lower incidence of fungal infections in their series. Goa has climatic conditions conducive for different cutaneous fungal infections. Bacterial and viral infections accounted for $3.9 \%$ and $3.4 \%$ of patients respectively in our study, the incidence being much lower than fungal infections. This is consistent with findings of other studies ${ }^{7,8}$. The incidence of scabies was (4.9\%) in our study which is consistent with other studies ${ }^{8,12}$. Leg ulcers in our series acounted for $(6.6 \%)$ of the patients while other series 5 , 10. reported a high incidence of (14.1\%) and (9.3\%) respectively. Fissured soles acounted for $(6.6 \%)$ of the patients in our study as against $30 \%$ noted by Patange V.S. et $\mathrm{al}^{8}$.

We found $3(0.7 \%)$ cases of malignancies in our series, 2 of which were squamous cell carcinoma and a single patient with cutaneous T Cell. lymphoma. This is a very important and significant finding in our study. Some workers $^{8,11}$ have not noted this finding while others ${ }^{6}$ reported a single case of malignant melanoma.

Among the ageing related hair changes graying of hair out numbered $(96.8 \%)$ other findings, unreported to date. The incidence of alopecia (non cicatricial) was (32.55\%) in our series. A slightly higher proportion of patients were reported by other studies ${ }^{(8)}$. Among the nail disorders, longitudinal ridges was the commonest seen in a maximum of $12.6 \%$ of patients in our group, lower than as reported by Patange V.S. et al $(19.5 \%)^{8}$. However Beaureegard $S$ et $\mathrm{al}^{9}$ reported a very high incidence of $85 \%$ of patients with Onychorrhexis in his series. We reported (7.3\%) of patient with subungal hyperkeratosis which is analogous (7\%) to Patange V.S ${ }^{\text {et }} \mathrm{al}^{8}$. The incidence of nail discoloration was (10.2\%) in our patients as opposed to $16 \%$ reported by other workers ${ }^{8}$.

Other nail disorders found in our study were onycholysis (7.5\%), pitting of nails (5.0\%), onychomycosis and distortion of the nails in $(5.8 \%)$ each, beau's lines and lusterless nails in (1.9\%) each, onychogryphosis (1.0\%), onychauxis and onychoszhia in $(0.7 \%)$ each, edema of nail folds and triangular nicking of nail in $(0.2 \%)$ of patient each. These workers have not made a mention of different nail disorders in their cases. Among the associated systemic diseases, diabetes mellitus was the commonest (16.8\%) followed by hypertension (9.2\%) while a smaller (3.6\%) number of cases had a combination of the two. This was also noted by Patange V. S et $\mathrm{al}^{8}$. We had a smaller (3\%) number of patients with other systemic disorders like IHD, CVA, CRF, Pulmonary Koch and liver cirrhosis. These finding were however not mentioned by others ${ }^{7,9,10,11}$

Out of the 411 patients, 266 patients were biopsied. Most of the histopathological features observed in our study correlated with the clinical findings. However few conditions like Seborrehoeic keratosis, skin tags did not show all the features mentioned in standard text books ${ }^{4}$.

Table No. 1

Diagnosis wise sex distribution of patients with Geriatric Dermatoses

\begin{tabular}{|c|c|c|c|c|}
\hline GERIATRIC DERMATOSES & 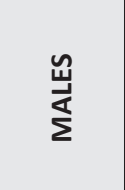 & 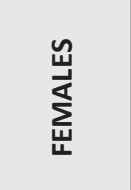 & 定 & 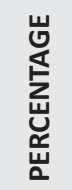 \\
\hline \multicolumn{5}{|l|}{ 1. Specific ageing changes } \\
\hline Wrinkling & $\begin{array}{c}266 \\
(64.8 \%)\end{array}$ & $\begin{array}{c}142 \\
(34.6 \%)\end{array}$ & 408 & 99.3 \\
\hline Graying of hair & $\begin{array}{c}259 \\
(63.0 \%)\end{array}$ & $\begin{array}{c}139 \\
(33.8 \%)\end{array}$ & 398 & 96.8 \\
\hline Senile pruritus & $\begin{array}{c}21 \\
(5.1 \%) \\
\end{array}$ & $\begin{array}{c}17 \\
(4.1 \%)\end{array}$ & 38 & 9.2 \\
\hline Xerosis & $\begin{array}{c}18 \\
(4.3 \%) \\
\end{array}$ & $\begin{array}{c}9 \\
(2.1 \%) \\
\end{array}$ & 27 & 6.6 \\
\hline Senile comedones & $\begin{array}{c}20 \\
(4.9 \%) \\
\end{array}$ & $\begin{array}{c}15 \\
(3.6 \%) \\
\end{array}$ & 35 & 8.5 \\
\hline Senile purpura & $\begin{array}{c}15 \\
(3.6 \%)\end{array}$ & $\begin{array}{c}2 \\
(0.5 \%)\end{array}$ & 17 & 4.1 \\
\hline 2. Benign Neoplasias & $\begin{array}{c}228 \\
(55.5 \%) \\
\end{array}$ & $\begin{array}{c}103 \\
(25.1 \%) \\
\end{array}$ & 331 & 80.5 \\
\hline $\begin{array}{l}\text { 3. Papulosquamous } \\
\text { disorders }\end{array}$ & $\begin{array}{c}39 \\
(9.5 \%) \\
\end{array}$ & $\begin{array}{c}12 \\
(3.0 \%)\end{array}$ & 51 & 12.4 \\
\hline $\begin{array}{l}\text { 4. Vesiculobullous dis- } \\
\text { orders }\end{array}$ & $\begin{array}{c}4 \\
(1.0 \%) \\
\end{array}$ & $\begin{array}{c}14 \\
(3.4 \%) \\
\end{array}$ & 18 & 4.4 \\
\hline 5. Eczemas & $\begin{array}{c}48 \\
(11.7 \%) \\
\end{array}$ & $\begin{array}{c}31 \\
(7.5 \%) \\
\end{array}$ & 79 & 19.2 \\
\hline 6. Bacterial infections & $\begin{array}{c}11 \\
(2.7 \%) \\
\end{array}$ & $\begin{array}{c}5 \\
(1.2 \%) \\
\end{array}$ & 16 & 3.9 \\
\hline 7. Fungal infections & $\begin{array}{c}56 \\
(13.6 \%) \\
\end{array}$ & $\begin{array}{c}29 \\
(7.0 \%) \\
\end{array}$ & 85 & 20.7 \\
\hline 8. Viral infections & $\begin{array}{c}11 \\
(2.7 \%)\end{array}$ & $\begin{array}{c}3 \\
(0.7 \%)\end{array}$ & 14 & 3.4 \\
\hline 9. Infestations & $\begin{array}{c}14 \\
(3.4 \%) \\
\end{array}$ & $\begin{array}{c}6 \\
(1.4 \%) \\
\end{array}$ & 20 & 4.9 \\
\hline 10. Leg ulcers & $\begin{array}{c}24 \\
(5.8 \%) \\
\end{array}$ & $\begin{array}{c}3 \\
(0.7 \%) \\
\end{array}$ & 27 & 6.6 \\
\hline
\end{tabular}




\begin{tabular}{|c|c|c|c|c|}
\hline 11. Pigmentary disorders & $\begin{array}{c}15 \\
(3.6 \%) \\
\end{array}$ & $\begin{array}{c}9 \\
(2.1 \%)\end{array}$ & 24 & 5.8 \\
\hline 12. Fissured soles & $\begin{array}{c}18 \\
(4.3 \%) \\
\end{array}$ & $\begin{array}{c}10 \\
(2.4 \%)\end{array}$ & 28 & 6.8 \\
\hline 13. Oral cavity disorders & $\begin{array}{c}9 \\
(2.1 \%) \\
\end{array}$ & $\begin{array}{c}4 \\
(1.0 \%) \\
\end{array}$ & 13 & 3.2 \\
\hline 14. Malignancies & $\begin{array}{c}3 \\
(0.7 \%)\end{array}$ & - & 3 & 0.7 \\
\hline 15. Drug rash & $\begin{array}{c}5 \\
(1.2 \%) \\
\end{array}$ & - & 5 & 1.2 \\
\hline 16. Pressure sores & $\begin{array}{c}6 \\
(1.4 \%) \\
\end{array}$ & $\begin{array}{c}6 \\
(1.4 \%)\end{array}$ & 12 & 2.9 \\
\hline $\begin{array}{l}\text { 17. Disorders due to sun } \\
\text { exposure }\end{array}$ & $\begin{array}{c}7 \\
(1.7 \%) \\
\end{array}$ & $\begin{array}{c}3 \\
(0.7 \%) \\
\end{array}$ & 10 & 2.4 \\
\hline $\begin{array}{l}\text { 18. Immune, rheumatic } \\
\text { disorders }\end{array}$ & $\begin{array}{c}8 \\
(1.9 \%) \\
\end{array}$ & $\begin{array}{c}9 \\
(2.1 \%) \\
\end{array}$ & 17 & 4.1 \\
\hline $\begin{array}{l}\text { 19. Tuberculosis verru- } \\
\text { cosa cutis }\end{array}$ & $\begin{array}{c}1 \\
(0.2 \%) \\
\end{array}$ & - & 1 & 0.2 \\
\hline 20. Hansen's & $\begin{array}{c}2 \\
(0.5 \%) \\
\end{array}$ & $\begin{array}{c}1 \\
(0.2 \%) \\
\end{array}$ & 3 & 0.7 \\
\hline 21. Xanthelesma & $\begin{array}{c}1 \\
(0.2 \%) \\
\end{array}$ & $\begin{array}{c}5 \\
(1.2 \%) \\
\end{array}$ & 6 & 1.4 \\
\hline 22. Callosities & $\begin{array}{c}1 \\
(0.2 \%) \\
\end{array}$ & $\begin{array}{c}3 \\
(0.7 \%) \\
\end{array}$ & 4 & 1.0 \\
\hline $\begin{array}{l}\text { 23. Erythema Multi- } \\
\text { forme }\end{array}$ & $\begin{array}{c}2 \\
(0.5 \%) \\
\end{array}$ & $\begin{array}{c}1 \\
(0.2 \%) \\
\end{array}$ & 3 & 0.7 \\
\hline 24. Darier's disease & $\begin{array}{c}1 \\
(0.2 \%) \\
\end{array}$ & - & 1 & 0.2 \\
\hline $\begin{array}{l}\text { 25. Lichen sclerosis et } \\
\text { atrophicus of vulva }\end{array}$ & - & $\begin{array}{c}1 \\
(0.2 \%)\end{array}$ & 1 & 0.2 \\
\hline
\end{tabular}

Figure 1

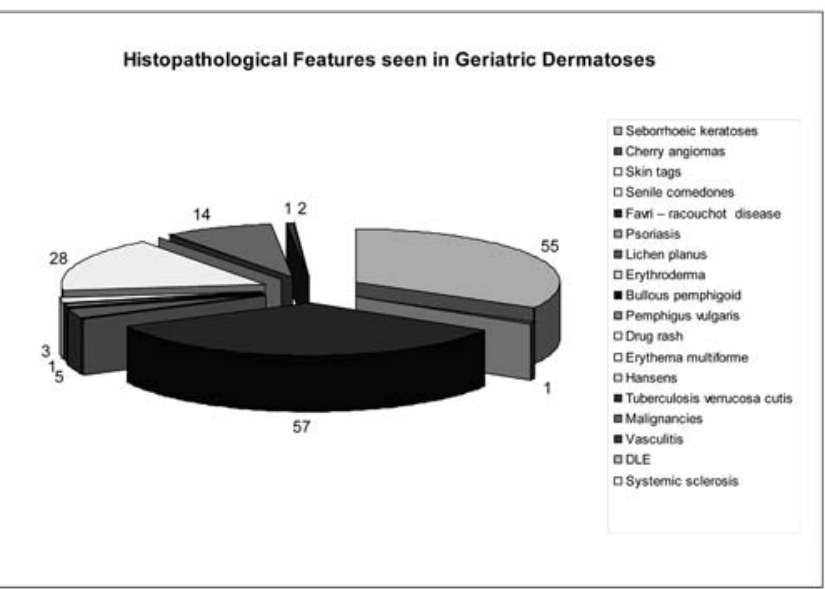

Figure 2

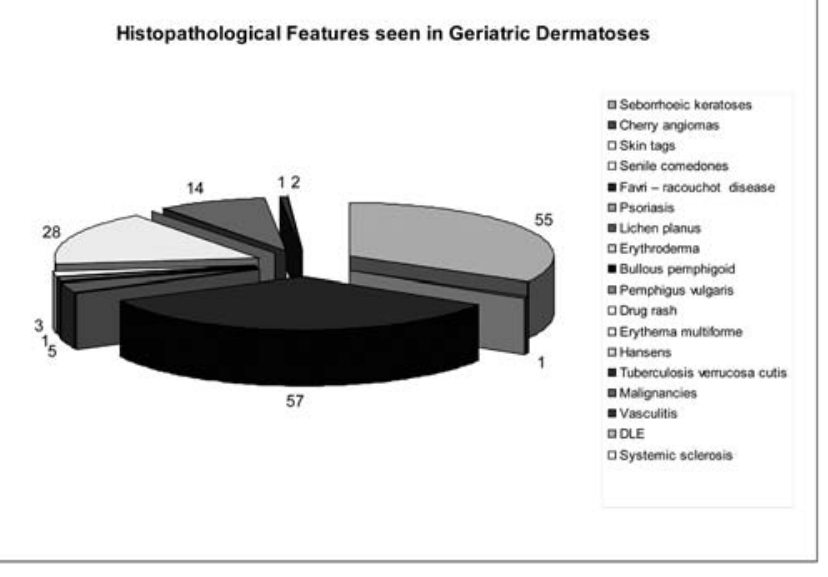

TABLE NO. 2. Histopathological features seen in Geriatric Dermatoses

\begin{tabular}{|c|c|c|c|c|c|c|c|c|c|c|c|c|c|c|c|c|c|c|c|c|}
\hline Dermatoses & 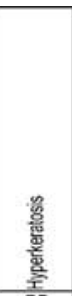 & 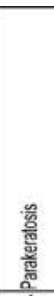 & 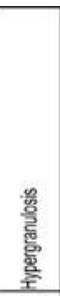 & 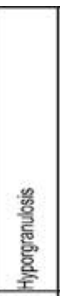 & 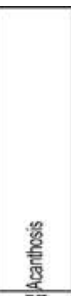 & $\begin{array}{l}\text { s. } \\
\text { s. } \\
\end{array}$ & 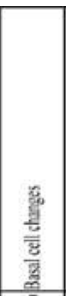 & 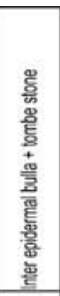 & 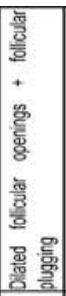 & $\begin{array}{l}\text { 言 } \\
\text { 妾 }\end{array}$ & 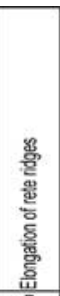 & 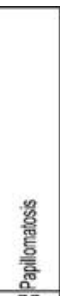 & 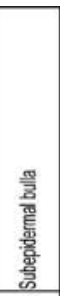 & 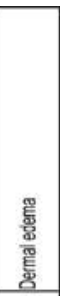 & 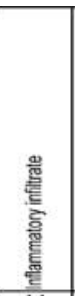 & 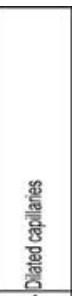 & 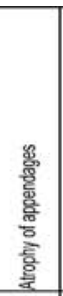 & 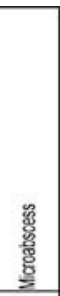 & 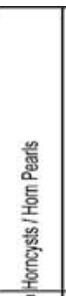 & 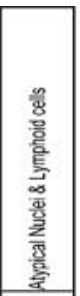 \\
\hline Seborrhoeic keratoses & $\begin{array}{cc}55 \\
13.4 \% \\
\end{array}$ & $0.2 \%$ & & & $\begin{array}{c}57 \\
13.9 \% \\
\end{array}$ & & \begin{tabular}{|c|}
5 \\
$1.2 \%$ \\
\end{tabular} & & & $0.2 \%$ & $0.7 \%$ & $\begin{array}{ll}28 \\
6.8 \% \\
\end{array}$ & & & $3.4 \%$ & $0.2 \%$ & & & $0.5 \%$ & \\
\hline Cherry angiomas & & & & & & & & & & & & & & & $0.2 \%$ & \begin{tabular}{|c|}
45 \\
$10.9 \%$ \\
\end{tabular} & & & & \\
\hline Skin tags & $\begin{array}{c}42 \\
10.2 \% \\
\end{array}$ & & & & $\begin{array}{c}42 \\
10.2 \% \\
\end{array}$ & & & & & $\begin{array}{c}5 \\
1.2 \% \\
\end{array}$ & $\begin{array}{c}3 \\
0.7 \% \\
\end{array}$ & $\begin{array}{l}11 \\
2.7 \% \\
\end{array}$ & & & $1.7 \%$ & $1.7 \%$ & & & & \\
\hline Senile comedones & & & & & & & & & \begin{tabular}{|l|l|}
21 \\
$5.1 \%$
\end{tabular} & $\begin{array}{c}18 \\
4.4 \% \\
\end{array}$ & & & & & $\begin{array}{r}13 \\
3.2 \% \\
\end{array}$ & & & & & \\
\hline Favri - racouchot disease & & & & & & & & & $0.2 \%$ & $0.2 \%$ & & & & & $0.2 \%$ & & & & & \\
\hline Psoriasis & $\begin{array}{r}20 \\
4.9 \% \\
\end{array}$ & $\begin{array}{l}1.4 \\
3.4 \% \\
\end{array}$ & & $1.0 \%$ & $\begin{array}{c}23 \\
5.6 \% \\
\end{array}$ & $\begin{array}{c}1 \\
0.2 \% \\
\end{array}$ & & & & & $\begin{array}{l}22 \\
5.3 \% \\
\end{array}$ & & & $\begin{array}{c}3 \\
0.7 \% \\
\end{array}$ & $\begin{array}{l}25 \\
6.1 \% \\
\end{array}$ & $\begin{array}{l}3 \\
0.7 \% \\
\end{array}$ & & $1.2 \%$ & & \\
\hline Lichen planus & $\begin{array}{r}13 \\
3.2 \% \\
\end{array}$ & & $\begin{array}{r}10 \\
2.4 \% \\
\end{array}$ & & $\begin{array}{r}13 \\
3.2 \% \\
\end{array}$ & $0.2 \%$ & \begin{tabular}{|l|}
12 \\
$2.9 \%$ \\
\end{tabular} & & & & $\begin{array}{l}4 \\
1.0 \% \\
\end{array}$ & & & & $\begin{array}{l}14 \\
3.4 \% \\
\end{array}$ & & & & & \\
\hline Erythroderma & $\begin{array}{l}5 \\
1.2 \% \\
\end{array}$ & & & & $\begin{array}{l}3 \\
0.7 \% \\
\end{array}$ & $\begin{array}{r}5 \\
1.2 \% \\
\end{array}$ & & & & & & & & & $\begin{array}{r}5 \\
1.2 \% \\
\end{array}$ & & & & & \\
\hline Bullous pemphigoid & $\begin{array}{l}2 \\
0.5 \% \\
\end{array}$ & & & & $0.2 \%$ & $1.7 \%$ & $0.1 \%$ & & & $\begin{array}{c}5 \\
1.2 \% \\
\end{array}$ & & & $\begin{array}{l}13 \\
3.2 \% \\
\end{array}$ & & $\begin{array}{l}13 \\
3.2 \% \\
\end{array}$ & & & & & \\
\hline Pemphigus vulgaris & & & & & & $0.5 \%$ & & $1.0 \%$ & & $0.5 \%$ & & & & & $1.0 \%$ & & & & & \\
\hline Drug rash & $0.3 \%$ & $0.1 \%$ & & & $\begin{array}{l}2 \\
2 \\
0.5 \% \\
\end{array}$ & $0.7 \%$ & \begin{tabular}{|l|}
2 \\
$0.5 \%$ \\
\end{tabular} & & & & & & & $0.7 \%$ & $\begin{array}{r}5 \\
1.2 \% \\
\end{array}$ & & & & & \\
\hline Erythema multiforme & $0.2 \%$ & & & & & $0.5 \%$ & $0.5 \%$ & & & & & & $0.7 \%$ & $0.2 \%$ & $0.7 \%$ & & & & & \\
\hline Hansens & & & & & & & & & & $0.7 \%$ & & & & & $0.7 \%$ & & & & & \\
\hline Tuberculosis verrucosa cutis & $0.2 \%$ & & $0.2 \%$ & & $0.2 \%$ & & & & & & & & & & $0.2 \%$ & & & & & \\
\hline Malignancies & $0.2 \%$ & & & & $0.2 \%$ & & & & & $0.2 \%$ & & & & & $0.5 \%$ & & & & $0.2 \%$ & $0.2 \%$ \\
\hline Vasculitis & & & & & & & & & & $0.2 \%$ & & & & & $0.5 \%$ & $0.2 \%$ & & & & \\
\hline DLE & $0.2 \%$ & & & & & & $0.5 \%$ & & $0.5 \%$ & $0.2 \%$ & & & & & $0.2 \%$ & & 0.2 & & & \\
\hline Systemic sclerosis & & & & & & & & & & $0.2 \%$ & & & & & $0.2 \%$ & & $0.2 \%$ & & & \\
\hline
\end{tabular}




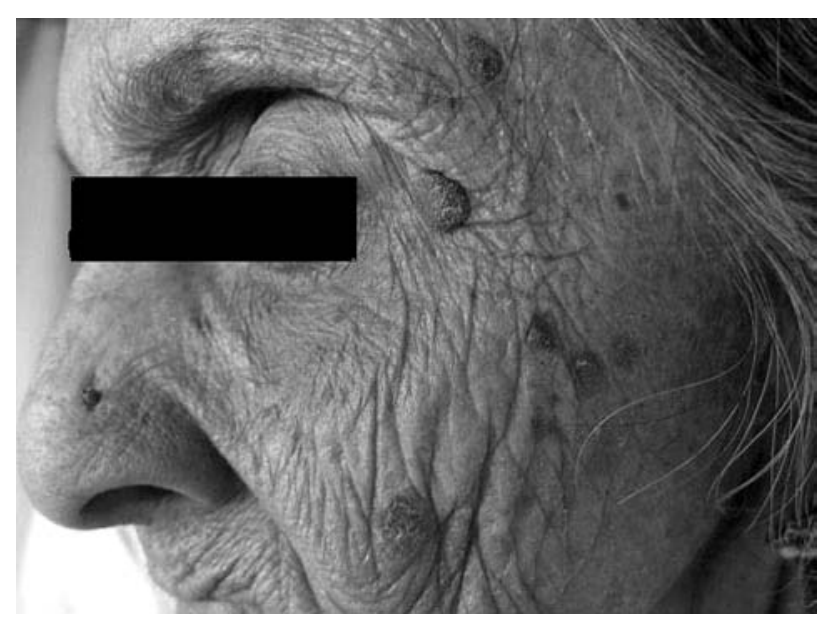

Fig 1 : Seborrhoeic Keratoses

\section{References}

1. Park K. Preventive medicine in obstetrics, pediatrics and geriatrics. In: Textbook of preventive and social medicine, $\mathrm{K}$. Park. $17^{\text {th }}$ edition; 2002: 409.

2. Graham Brown R. A. C. The ages of man and their dermatoses. In: Rook's Textbook of dermatology. Vol 4, $7^{\text {th }}$ edition. Burns T., Brethnach S., Cox N., Griffiths C. editors. Blackwell publishing, London; 2004 : 70.1-70.30

3. Havlik NL, Fitzpatrick T. B., Klingman A. M., Kligman L.H. Geriatric dermatology. In: dermatology in general medicine. Freedberg I.M., Eiseen A.Z., Wolff K., Austen K.F., Goldsmith L.A., Kats S.I., Fitzpatrick T.B. editors. $5^{\text {th }}$ edition Mc Graw-Hill, New York, 1999 : 1707-1723.

4. Yaar M., Gilchrist B.A. Ageing of skin. In: Dermatology in general medicine. Freedberg I.M., Eiseen A.Z., Wolff K., Austen K.F., Goldsmith L.A., Kats S.I., Fitzpatrick T.B. editors. $5^{\text {th }}$ edition. McGraw-Hill, New York, 1999: 1682-1706.

5. Verbov J. Skin problems in the older patients. The practitioner Nov 1975; 215: 612-22.

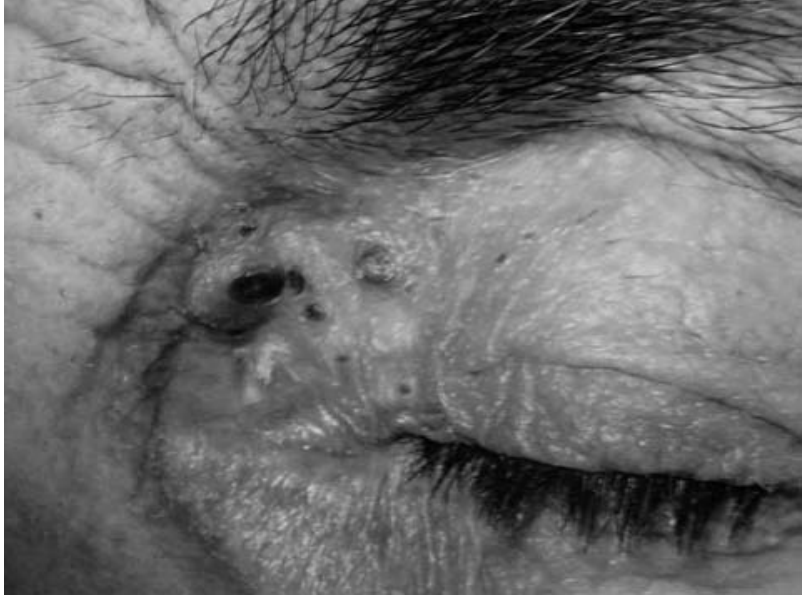

Fig 2 : Senile Comedones

6. Chopra A. Skin diseases in the elderly Ind J. dermatol Leprol Venereol. 1999; 65:245-46.

7. Lane C. G., Rockwood E. M. Geriatric dermatoses. N. Engl J Med 1949; 241: 772-7.

8. Patange V. S., Fernandes R. J. A study of geriatric dermatoses. Ind J. Dermatol Venereol Leprol 1995; 61: 206-8.

9. Beauregard S, Gilchrest B.A., a survey of skin problems and skin care regimens in the elderly. Arch dermatol Dec 1987;123:163843.

10. Mc Fadden $\mathrm{N}$ and Hande K. A survey of elderly new patients at dermatology outpatients clinic. Acta Derm Venereol (Stock) 1989;69:262-4.

11. Weismann K., Krakauer R. and Wanscher B. Prevalence of skin diseases in old age. Acta Derm Venereol 1980; 60: 352-3.

12. Yalcin B., Taner E., Toy G., Oztas P., Hayran M., Alli N. The prevalance of skin diseases in the elderly: analysis of 4099 geriatric patients. Int J Dermatol 2006 Jun; 45(6): 672-6. 